\title{
Influence of Fiber Addition on the Properties of High-Performance Concrete
}

\author{
Szymon Grzesiak ${ }^{1}$, Matthias Pahn ${ }^{1, *}$, Milan Schultz-Cornelius ${ }^{1}$, Stefan Harenberg ${ }^{2}$ and Christoph Hahn ${ }^{3}$ \\ 1 Department of Civil Engineering, Technical University of Kaiserslautern, 67663 Kaiserslautern, Germany; \\ szymon.grzesiak@bauing.uni-kl.de (S.G.); milan.schultz-cornelius@bauing.uni-kl.de (M.S.-C.) \\ 2 Implenia Schalungsbau GmbH, 67240 Bobenheim-Roxheim, Germany; stefan.harenberg@implenia.com \\ 3 Master Builders Solutions Deutschland GmbH, 68199 Mannheim, Germany; \\ christoph.hahn@mbcc-group.com \\ * Correspondence: matthias.pahn@bauing.uni-kl.de
}

Citation: Grzesiak, S.; Pahn, M.; Schultz-Cornelius, M.; Harenberg, S.; Hahn, C. Influence of Fiber Addition on the Properties of High-Performance Concrete. Materials 2021, 14, 3736. https:// doi.org/10.3390/ma14133736

Academic Editor: Alessandro P. Fantilli

Received: 31 May 2021

Accepted: 29 June 2021

Published: 3 July 2021

Publisher's Note: MDPI stays neutral with regard to jurisdictional claims in published maps and institutional affiliations.

Copyright: (c) 2021 by the authors. Licensee MDPI, Basel, Switzerland. This article is an open access article distributed under the terms and conditions of the Creative Commons Attribution (CC BY) license (https:/ / creativecommons.org/licenses/by/ $4.0 /)$.

\begin{abstract}
High performance fiber-reinforced concrete (HPFRC) has been frequently investigated in recent years. Plenty of studies have focused on different materials and types of fibers in combination with the concrete matrix. Experimental tests show that fiber dosage improves the energy absorption capacity of concrete and enhances the robustness of concrete elements. Fiber reinforced concrete has also been illustrated to be a material for developing infrastructure sustainability in RC elements like façade plates, columns, beams, or walls. Due to increasing costs of the produced fiber reinforced concrete and to ensure the serviceability limit state of construction elements, there is a demand to analyze the necessary fiber dosage in the concrete composition. It is expected that the surface and length of used fiber in combination with their dosage influence the structure of fresh and hardened concrete. This work presents an investigation of the mechanical parameters of HPFRC with different polymer fiber dosage. Tests were carried out on a mixture with polypropylene and polyvinyl alcohol fiber with dosages of 15,25 , and $35 \mathrm{~kg} / \mathrm{m}^{3}$ as well as with control concrete without fiber. Differences were observed in the compressive strength and in the modulus of elasticity as well as in the flexural and splitting tensile strength. The flexural tensile strength test was conducted on two different element shapes: square panel and beam samples. These mechanical properties could lead to recommendations for designers of façade elements made of HPFRC.
\end{abstract}

Keywords: high performance fiber reinforced concrete (HPFRC); polypropylene fiber (PP); polyvinyl alcohol fiber (PVA); compressive strength; residual flexural strength; splitting tensile strength

\section{Introduction}

Since the development of concrete, RC constructions allow for more and more filigree and lightweight elements with the contemporary growth of structure loads [1]. Reduced cross-sections of components are associated with advanced technologies and materials based on higher material properties [2]. With an increase in concrete specifications like compressive strength, the post crack behavior of concrete becomes worse. In concrete compositions, different kinds of fibers are added to avoid brittle fracture behavior and ameliorate the ductility of those materials [3]. Fiber reinforcement concrete (FRC) has already been used successfully in many horizontal and vertical structural as well as nonstructural elements [4]. For example, using fiber reinforcement together with traditional steel bar reinforcement decreases crack propagation and displacement of concrete slabs like industrial floors [5]. In buildings and bridges in seismic areas, fiber reinforced concrete improves the behavior of structural parts like columns, beams, or walls [6].

Recently, FRC has also been used for the production of pre-cast elements in which the fibers - in combination with ultra-high-performance concrete-enhance the durability of cracked concrete [7]. As studies show, a decisive role is played by the dense microstructure of concrete pre-cast elements. This can be ensured by low water-cement and water-binder 
ratios. Mateckova et al. [8] report that high-performance concrete with its dense structure presents higher resistance to chemical penetration in comparison to ordinary concrete. The character of used materials in HPC can improve the acid attack by FRC through better integrity of the binder matrix to fiber inclusion. Ali et al. [9] showed the influence of fibers and silica fume on the mechanical and durability performance of concrete concerning a reduction in the materials' permeability.

The possible benefits of using HPFRC are in sustainable resource management. A good example for the use of FRC are façade panels in building constructions, leading to a considerable reduction in the material volume [10]. Therefore, the major advantage of fiberreinforced concrete elements is the reduced thickness, thus leading to a reduction in $\mathrm{CO}_{2}$ footprint. Without steel rebars, façade panels can be just a few centimeters thick [11]. For concrete elements without steel reinforcement, a corrosion protection system like concrete cover can be omitted [12].

Vertical exterior elements of buildings exposed to environmental factors are investigated for structural performance under gravity and wind load. Concrete elements such as façade panels for certain boundary conditions are under flexural load. The wind pressure is distributed as area load, which causes tensile and compressive stresses in the cross-section of the building's façade and results in deformation [13]. Therefore, exterior elements are designed to transfer loads to the main structural system of the building. This is why the flexural tensile strength of fiber reinforced concrete is one important design parameter [14]. Moreover, the impact of panel behavior and damage to the FRC is evaluated as a safety factor.

To understand the behavior of HPC and UHPC as well as concrete in general with fiber addition, scientific measurement methods in experimental research study have recently been published [15]. Typical fibers for HPFRC are made of steel [16], carbon [17], or polymers [18]. Examining the available research literature demonstrates that another material like wool [19], basalt [20], or glass [21] could be successfully added to concrete. The fibers differ according to their origin, mechanical properties, and their corrosion resistance [22]. The analysis of this material focuses particularly on a unique combination of concrete and fiber reinforcement [23]. The damage process and the mechanical properties of HPFRC can be taken into account for different dimensions and different shapes of samples [24]. Results of the experimental tests should implement the anisotropy of fiber orientation in the concrete matrix [25]. The location of deformation and the position of the cracked zone can lead to difficulties during examination [26]. By means of a clip gauge, it is possible to estimate the behavior of specimens in the cracked region. The clip gauge is used to measure the crack mouth opening displacement (CMOD) [27]. The details of the classic experimental setup and the examination with a clip gauge will be presented in the Section 2.

The aim of this work was to investigate the influence of fiber addition on the properties of high-performance concrete. As is known from other publications, the addition of fiber does not always have a positive effect on the mechanical properties. Other studies have also focused on other types of fibers in connection with HPFRC. Therefore, in this study, it was proposed to also consider the fiber type and shape variation of the concrete sample. Furthermore, this paper expands the database with an overview of the mechanical properties in HPFRC with polypropylene and polyvinyl alcohol fiber. It is suspected that the surface and length of used fiber influence the structure of fresh and hardened concrete. Optimization and a better quantity of fiber dosage will allow for a reduction and also a better use of the materials in the concrete mix design. Mechanical parameters of HPFRC enable the economical design of filigree, safe, and lightweight elements. 


\section{Experimental Program \\ 2.1. Materials}

In this study, only fine aggregates and particles were used to improve the homogeneity of high-performance concrete [28]. In the following sections, the properties of the fibers and the concrete mix design are discussed.

\subsubsection{Fiber}

In this study, the influence of two fiber types on the fresh concrete and the mechanical properties of hardened concrete is investigated: polypropylene fibers (PP) and polyvinyl alcohol fibers (PVA) (see Figure 1). The characteristic of PP- and PVA-fibers are given in Table 1. Compared to steel, both fibers are corrosion-resistant.
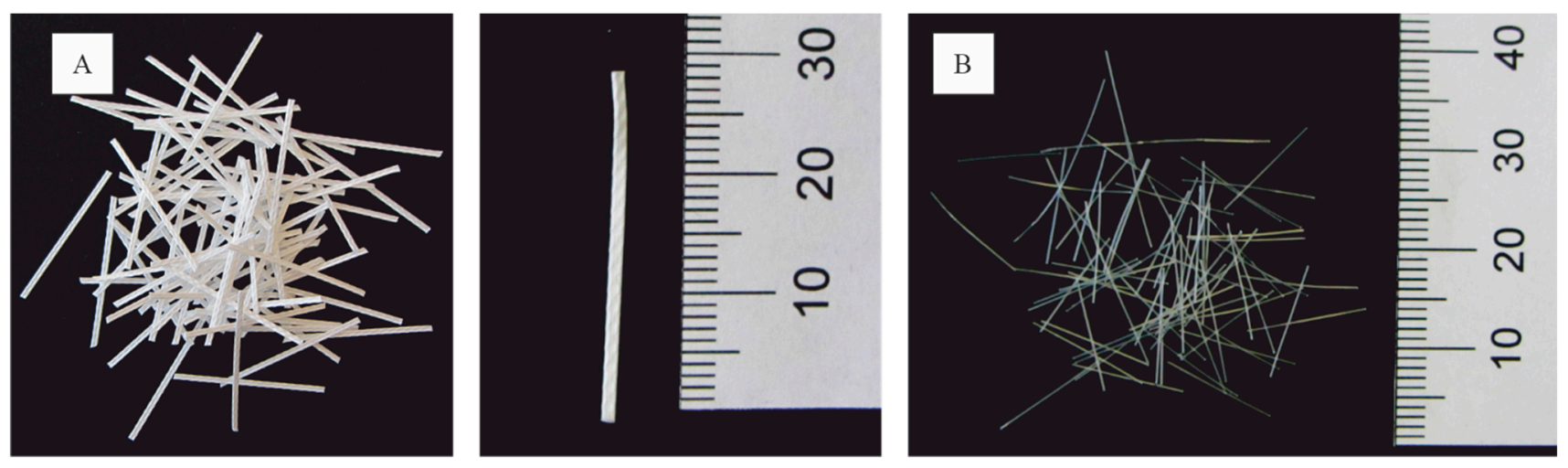

Figure 1. (A) Polypropylene fiber MasterFiber 235 SPA (PP). (B) Polyvinyl alcohol fiber MasterFiber 401(PVA) used in the present study.

Table 1. Mechanical parameters of the used fiber.

\begin{tabular}{|c|c|c|c|c|c|}
\hline Type of Fiber & $\begin{array}{c}\text { Tension Strength } \\
{[\mathrm{MPa}]}\end{array}$ & $\begin{array}{c}\text { E-Modul } \\
{[\mathrm{MPa}]}\end{array}$ & $\begin{array}{c}\text { Diameter } \\
{[\mathrm{mm}]}\end{array}$ & Length [mm] & $\begin{array}{c}\text { Specific Gravity } \\
{\left[\mathrm{kg} / \mathrm{m}^{3}\right]}\end{array}$ \\
\hline MasterFiber 235 SPA (PP) & 500 & $>8.000$ & 0.70 & 30 & 910 \\
\hline MasterFiber 401 (PVA) & 800 & 29.000 & 0.16 & 12 & 1.300 \\
\hline
\end{tabular}

\subsubsection{Concrete Mix Design}

For this experimental research, five different concrete mixtures with the same amount of cement, aggregates, and additives (Table 2) were prepared. They only differed in the fiber type (Table 1) and fiber dosage (Table 3). Mix ID 1 contained $35 \mathrm{~kg} / \mathrm{m}^{3}$ of the MasterFiber 401 (PVA). For comparison with the MasterFiber 235 SPA (PP), Mix ID 2 contained $35 \mathrm{~kg} / \mathrm{m}^{3}$. To investigate the influence of the fiber dosage, Mix IDs 3,4 , and 5 contained $25 \mathrm{~kg} / \mathrm{m}^{3}$, $15 \mathrm{~kg} / \mathrm{m}^{3}$, and $0 \mathrm{~kg} / \mathrm{m}^{3}$ of fibers, respectively. The mixtures were prepared by using a 55-L-capacity horizontal forcing type concrete mixer.

Table 2. Concrete mix design.

\begin{tabular}{ccc}
\hline Material & Raw Density $\left[\mathbf{k g} / \mathbf{m}^{\mathbf{3}}\right]$ & Weight $\left[\mathbf{k g} / \mathbf{m}^{\mathbf{3}}\right]$ \\
\hline Cement (CEM I 42.5 R) & 3100 & 650 \\
Aggregate 0 to 3 mm & 2600 & 990 \\
Silica fume & 700 & 50 \\
Limestone powder & 2700 & 415 \\
Plasticizer MasterGlenium ACE 430 & 1060 & 18 \\
Water & 1000 & 210 \\
\hline
\end{tabular}


The appropriated HPFRC was produced with cement CEM I 42.5 R [29], quartz sand $0.1 / 0.6$ [30], limestone powder, and silica fume. The limestone powder and the silica fume provide a dense microstructure of concrete and are used as fillers. The aggregates were dried sand and basalt [31]. Figure 2 presents the grain size curve of the material used in the present study [32]. For better workability, a plasticizer, MasterGlenium ACE 430, was used [33]. The water-cement $(\mathrm{w} / \mathrm{c})$ and water-binder $(\mathrm{w} / \mathrm{b})$ ratio in the concrete composition was 0.323 and 0.238 , respectively.
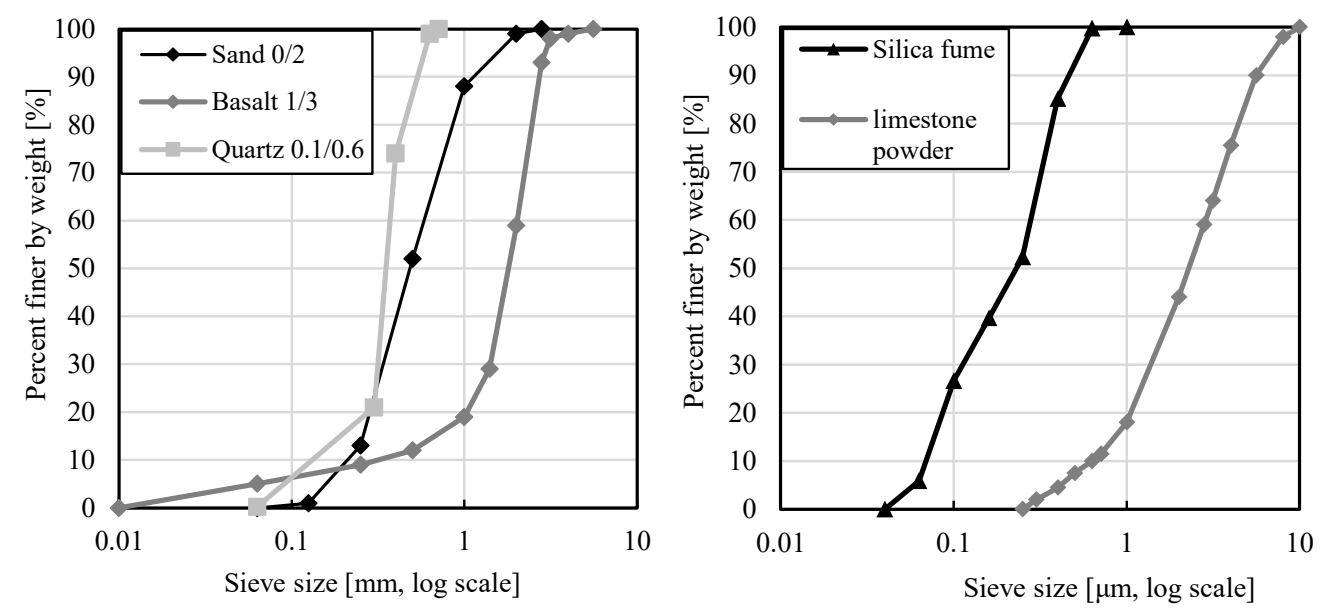

Figure 2. Grading of the fines for the material used in the present study. Sand, basalt, and quartz own studies. Silica fume [34], limestone powder [35].

\subsection{Testing Procedure}

In this study, tests were carried out on fresh and hardened high-performance concrete with and without fibers. The compressive strength tests on the hardened concrete were performed on $150 \mathrm{~mm}$ cubes according to EN 12390-1 [36]. Cylinders of $150 \mathrm{~mm}$ in diameter and $300 \mathrm{~mm}$ in height were used to test the modulus of elasticity and splitting tensile strength according to EN 12390-3 [37].

Table 3. Overview of tested samples.

\begin{tabular}{ccc}
\hline Series & Fiber Dosage $\left[\mathbf{k g} / \mathbf{m}^{3}\right]$ & Number of Specimens \\
\hline panel specimens & 0 & 3 \\
$\left(250 \times 250 \times 35 \mathrm{~mm}^{3}\right)$ in & 15 & 3 \\
accordance with EN 12467 [38] & 25 & 3 \\
\hline beam specimens & 35 & 3 \\
$\left(100 \times 100 \times 400 \mathrm{~mm}^{3}\right)$ in & 0 & 3 \\
accordance with EN 14651 [39] & 15 & 3 \\
\hline
\end{tabular}

A test program based on the different fiber dosage was conducted (Table 3). The flexural tensile strength test was conducted on square panel specimens $\left(250 \times 250 \times 35 \mathrm{~mm}^{3}\right)$ in accordance with EN 12467 [38] and beam specimens with a cross-section $(100 \times 100$ $\times 400 \mathrm{~mm}^{3}$ ) in accordance with EN 14651 [39]. For comparison purposes in both tests, we used the classical measurement method with the force-displacement relationship. Simultaneously, for the measurements of beam deformation, we applied the test method of crack mouth opening displacement (CMOD), which has been recently mentioned in the experimental investigations of HPFRC [27,40]. For this purpose, the bottom surface of the beam specimens had a notch with a depth of $17 \mathrm{~mm}$ and a width of $5 \mathrm{~mm}$ according to the procedure in EN 14651 [39] (see Figure 3). The notch was milled for the determination of 
strain during the crack initiation in the middle of the span. Near the notch were glued metal plates to attach the clip gauge (see Figure 4). The clip gauge measures the displacement between two points that are on two different edges of the crack [41].
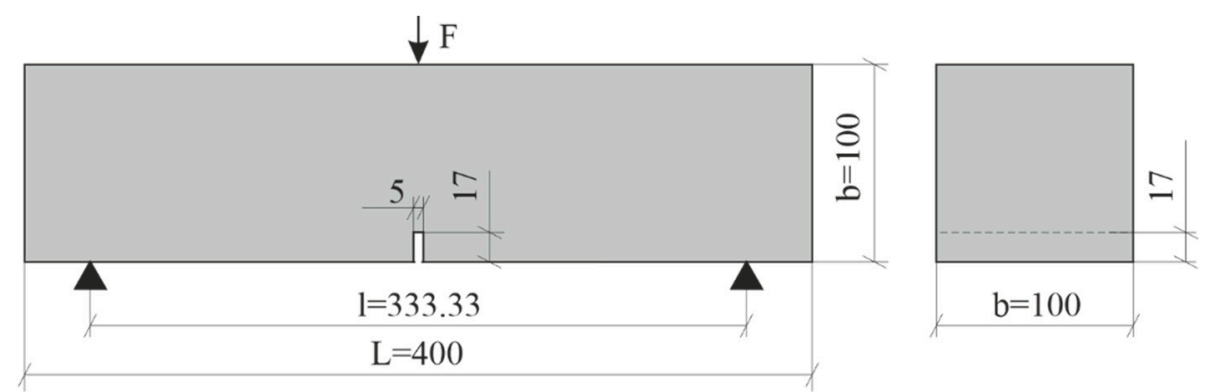

Figure 3. Beam specimen geometry. Dimensions in [mm].

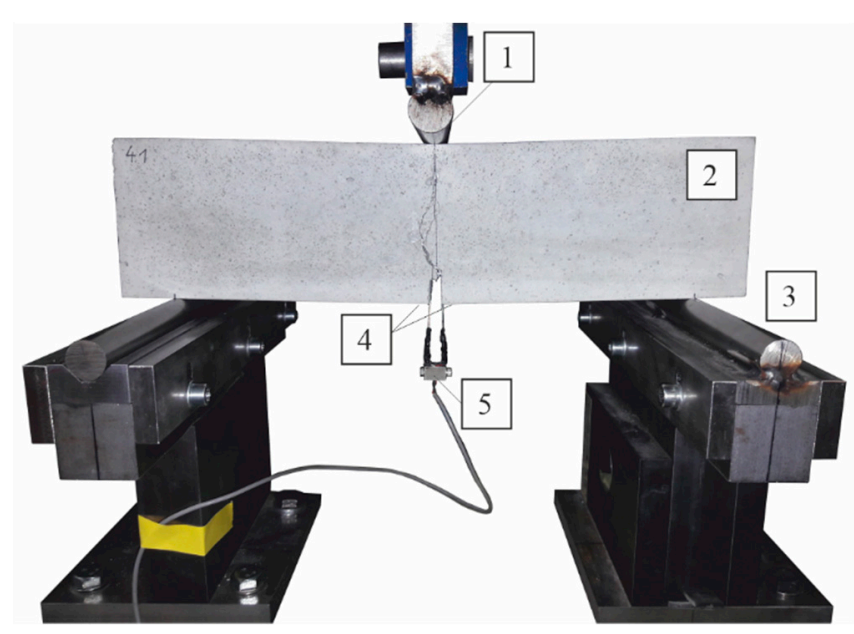

Figure 4. Experimental setup: 1 = point of application of symmetrical load, $2=$ HPFRC beam specimen, 3 = supports, 4 = glued on metal plates to attach the clip gauge, $5=$ clip gauge.

As shown in a study by Bi et al. [42], the distribution of fiber during concrete flow influences the mechanical properties of HPFRC. Mostly, fibers are randomly distributed but computer tomography shows that fibers accumulate in the upper part of the specimens. It has been observed that the flexural strength of HPFRC is higher with more fibers located in the tension zone. Therefore, during the bending tests, the upper side of the beams is turned backwards.

Three-point bending tests were carried out on plates and beams in order to be able to estimate the flexural strength [38]. The stresses $f_{L}$ were calculated according to the fib Model Code 2010 [43], as follows:

$$
f_{L}=\frac{3 \cdot F \cdot l}{2 \cdot b \cdot h^{2}}
$$

where $\mathrm{F}$ represents the cylinder force in $[\mathrm{N}] ; \mathrm{b}$ and $\mathrm{h}$ are the width and height of the specimens, respectively; and $l$ is the distance of the supports. The distance for the plates equaled $l=0.75 \cdot L$ and for the beams, $l=b / 0.3$. Dimensions are provided in [mm].

In their study, Schultz-Cornelius [24] investigated flexural strength for many different thicknesses of façade panels separately. They observed an effect in size for specimens with a depth below $50 \mathrm{~mm}$. The tests showed a linearly increasing bending tensile strength with decreasing thickness. In order to examine the impact of fiber dosage on the bending tensile strength, only panels with a thickness of $35 \mathrm{~mm}$ were tested.

The specimens were cured and stored at a temperature of $20^{\circ} \mathrm{C}$ and a relative air humidity of $60 \%$. Each test on hardened concrete was performed after $30 / 31$ days. The measurements were processed by Catman AP software. All bending tests were performed 
based on controlled displacement with the same testing speed and the same measuring rate of clip gauge.

\section{Analysis of the Results}

In this study, the properties of fresh concrete as well as the mechanical parameters of hardened concrete like compressive strength, modulus of elasticity, bending, and splitting tensile strength were investigated. The test results are discussed in the following sections.

\subsection{Properties of Fresh Concrete}

The slump test was performed according to EN 12350-5 [44]. The results presented in Table 4 show that both PP and PVA fibers performed well during the slump flow test. The slump flow diameter was measured on the base plate in two directions, from which the average value was calculated. It should be mentioned that the plasticizer MasterGlenium ACE 430 dosage in each concrete mixture was identical. With increasing fiber dosage, the workability of HPFRC increases. Tests show that the slump flow measure increased from $595 \mathrm{~mm}$ to $650 \mathrm{~mm}$ based on a PP fiber dosage of $15 \mathrm{~kg} / \mathrm{m}^{3}$ and $35 \mathrm{~kg} / \mathrm{m}^{3}$. The phenomenon of higher fiber dosage and a concurrently larger slump flow diameter was also observed in investigations of self-compacting concrete with PP and steel fiber batches [45]. For HPFRC with PVA fibers, a smaller slump flow diameter is recognized than for HPFRC with PP fibers. If a PVA fiber with a smaller diameter is used, the mixtures tend to absorb much more water and hence change the consistency of fresh concrete. This is due to the high specific surface area of PVA fibers. Chen [46] reported that fine fibers were responsible for reducing the mixture workability and suggested a combination of small and medium fibers for the best balance of fresh concrete and hardened material properties. The progress of the slump experiment and a picture of a fresh concrete mixture are shown in Figure 5.

Table 4. Fresh concrete properties of the investigated concrete mixtures.

\begin{tabular}{cccccc}
\hline $\begin{array}{c}\text { Mix } \\
\text { ID }\end{array}$ & Type of Fiber & $\begin{array}{c}\text { Fiber- } \\
\text { Dosage }\end{array}$ & $\begin{array}{c}\text { Air } \\
\text { Void }\end{array}$ & $\begin{array}{c}\text { Bulk Density } \\
\text { [st. dev] }\end{array}$ & $\begin{array}{c}\text { Slump Flow Diameter } \\
\text { [st. dev] }\end{array}$ \\
\hline & & {$\left[\mathbf{k g} / \mathbf{m}^{\mathbf{3}}\right]$} & {$[\%]$} & {$\left[\mathbf{k g} / \mathbf{m}^{\mathbf{3}}\right]$} & {$[\mathrm{mm}]$} \\
\hline \multirow{2}{*}{1} & MasterFiber & 35 & 3.8 & $2288[6]$ & $418[25]$ \\
& $401(\mathrm{PVA})$ & & & & \\
\hline 2 & & 35 & 4.2 & $2239[8]$ & $650[42]$ \\
3 & MasterFiber & 25 & 3.8 & $2251[21]$ & $635[21]$ \\
4 & 235 SPA (PP) & 15 & 3.5 & $2278[16]$ & $595[7]$ \\
5 & & 0 & 2.8 & $2307[20]$ & $565[7]$ \\
\hline
\end{tabular}
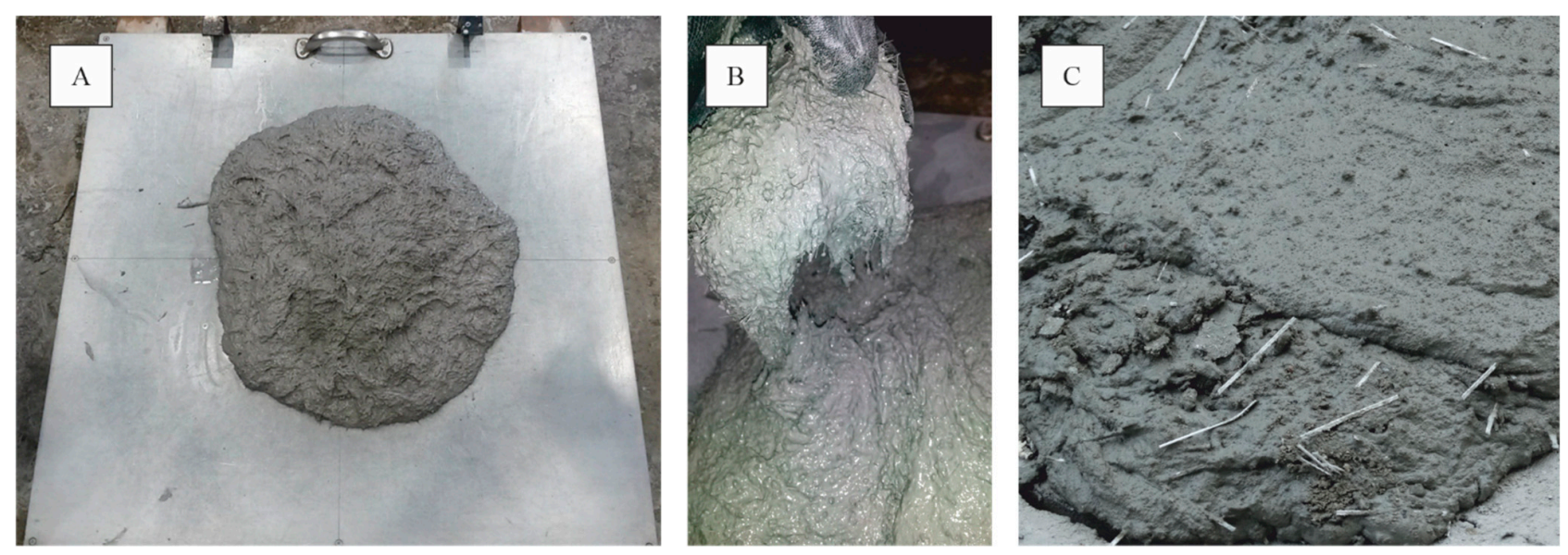

Figure 5. (A) Slump experiment for MasterFiber 401 (PVA). (B) Fresh concrete with MasterFiber 401 (PVA). (C) Fresh concrete with MasterFiber 235 SPA (PP). 
Table 4 shows the air depending on the fiber dosage of each mixture. This was determined according to EN 12350-7 [47]. The concrete with less pore volume had a higher bulk density. Furthermore, the air impacts mechanical properties like compressive strength and modulus of elasticity. Hassan [48] stated that concrete with lower porosity was resistant against chloride penetration. Furthermore, it showed a lower fluid and gas permeability, which impacts the frost resistance of HPFRC.

\subsection{Compressive Strength}

Figure 6 shows the compressive strength of the concrete after 28 days with different fiber dosages. The results showed that the compressive strength decreased with increasing fiber dosage. Lower dosages of fiber in normal concrete, in contrast, behave differently (e.g., under $30 \mathrm{MPa}$ ). In general, the mechanical properties of concrete with a lower compressive strength will be improved through the addition of fibers $[49,50]$. The space between concrete and fibers is filled with air, which already starts to accumulate during the mixing process between the adhesive surfaces. The air voids are linked to the small interaction between the PP and the cement paste. A small air volume reduces the compressive strength of high-performance concrete. Furthermore, the higher fiber dosage reduces the volume of the concrete-matrix dosage and at the same time reduces the compressive strength and modulus of elasticity of the concrete.

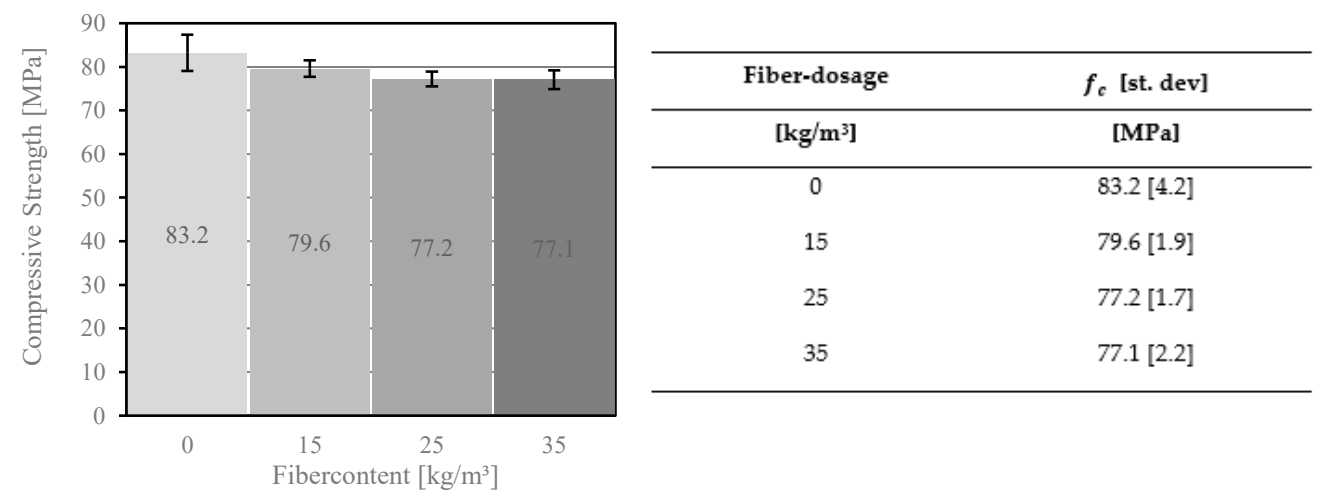

Figure 6. Compressive strength results of concrete with different fiber dosages of MasterFiber 235 SPA (PP).

\subsection{Modulus of Elasticity}

The modulus of elasticity was determined according to EN 12390-13 [51]. Figure 7 shows the test results for the cylindrical specimens [36]. The modulus of elasticity's value depends on the fiber dosage. An increase in the volume fraction of PP fiber in concrete leads to a decrease of the modulus of elasticity, which is due to the compressive strength of HPFRC. Similar results were obtained in a study on fiber reinforced concrete with a compressive strength up to $100 \mathrm{MPa}$ [52].

\subsection{Splitting Tensile Strength}

The addition of fibers to the concrete mix has a major impact on the tensile strength of FRC. The test results showed an increase from $4 \mathrm{MPa}$ for concrete without any fibers to $6.9 \mathrm{MPa}$ for concrete with a fiber dosage of $35 \mathrm{~kg} / \mathrm{m}^{3}$ (see Figure 8). Furthermore, the results showed that the difference in the splitting tensile strength between a fiber dosage of $25 \mathrm{~kg} / \mathrm{m}^{3}$ and $35 \mathrm{~kg} / \mathrm{m}^{3}$ was lower compared to a fiber dosage of $15 \mathrm{~kg} / \mathrm{m}^{3}$ and $25 \mathrm{~kg} / \mathrm{m}^{3}$. It can be assumed that this effect is caused by the strength of the fiber-matrix interface. The strength depends on the volume of the concrete surrounding the fibers. With increasing fiber dosage, this volume decreases and hence the pull-out-strength of the fibers in the cracking zone is reduced. It can therefore be concluded that the splitting tensile strength was at most $72.5 \%$ higher due to the addition of fibers. 


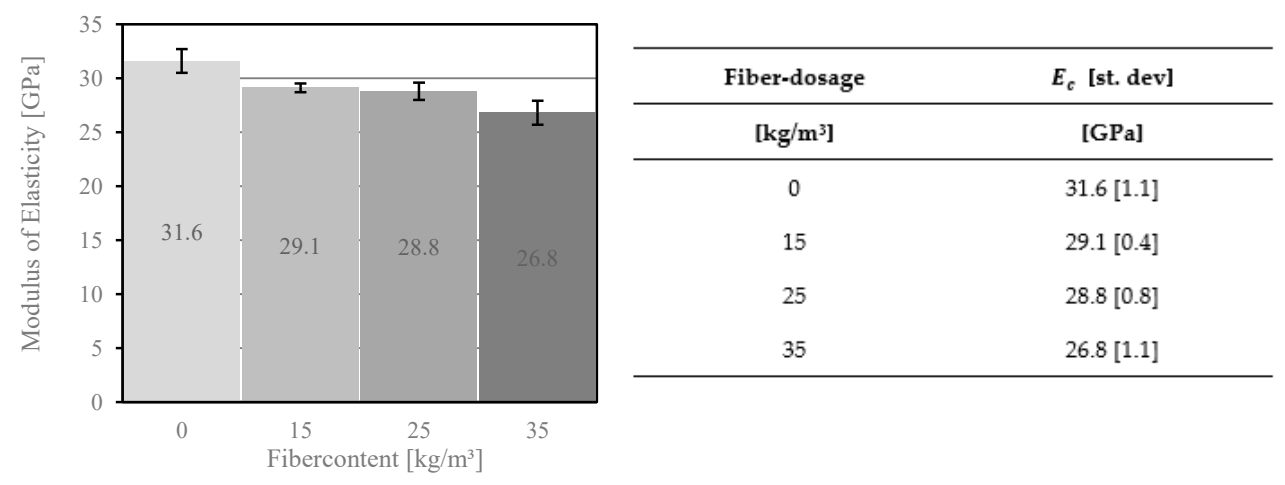

Figure 7. Modulus of elasticity of concrete with different fiber dosages of MasterFiber 235 SPA (PP).

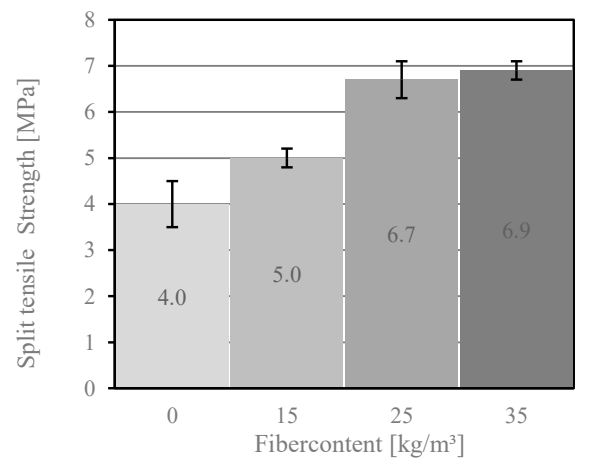

\begin{tabular}{cc}
\hline Fiber-dosage & $\boldsymbol{f}_{c t}$ [st. dev] \\
\hline$\left[\mathrm{kg}^{\mathbf{m}}{ }^{3}\right]$ & {$[\mathrm{MPa}]$} \\
\hline 0 & $4.0[0.5]$ \\
15 & $5.0[0.2]$ \\
25 & $6.7[0.4]$ \\
35 & $6.9[0.2]$ \\
\hline
\end{tabular}

Figure 8. Split tensile strength of concrete with different fiber dosages of MasterFiber 235 SPA (PP).

\subsection{Residual Flexural Strength}

For façade panels, the most important mechanical property is the bending tensile strength [53]. Fibers in concrete enhance the concrete's mechanical properties. They absorb post-crack energy and improve ductility of the FRC. For thin concrete elements like façade panels, a higher bending tensile strength leads to an improved resistance against area loads caused by wind and impacts.

The experimental setup and the dimensions of the test specimens are discussed in Section 3. The plates according to EN 12467 [38] reached higher bending-tensile strengths up to $10.5 \mathrm{MPa}$ for a fiber dosage of $35 \mathrm{~kg} / \mathrm{m}^{3}$. The test results with average values for plates with PP fiber are presented in Figure 9.

The stress-deflection curves in Figure 9 show a linear behavior at the beginning of the loading. After the first crack, stress deflection curves are non-linear. In HPFRC, the deflection, and concurrently the stress, still increases. Once the maximum value of stress has been reached, they decrease slowly. A similar effect of decreasing stresses after the first crack was described by the Association Francaise de Genie Civil [54] (AFGC). In concrete without fibers, the stress-deflection curves reached 5.61 MPa after the first crack and then collapsed. In contrast, the specimens with fiber dosage had an inclined plateau phase. This behavior is facilitated by a bond length of the PP fibers in the fiber-matrix interface, which is activated as soon as a crack occurs. The longer the bond of the anchored fiber, the greater the pull-out force. This behavior is the so-called bridging effect [55]. According to the first crack [38], it was possible to estimate the bending tensile strength of the concrete with fiber and concrete without fiber. The results with different fiber dosages are presented in Table 5. 

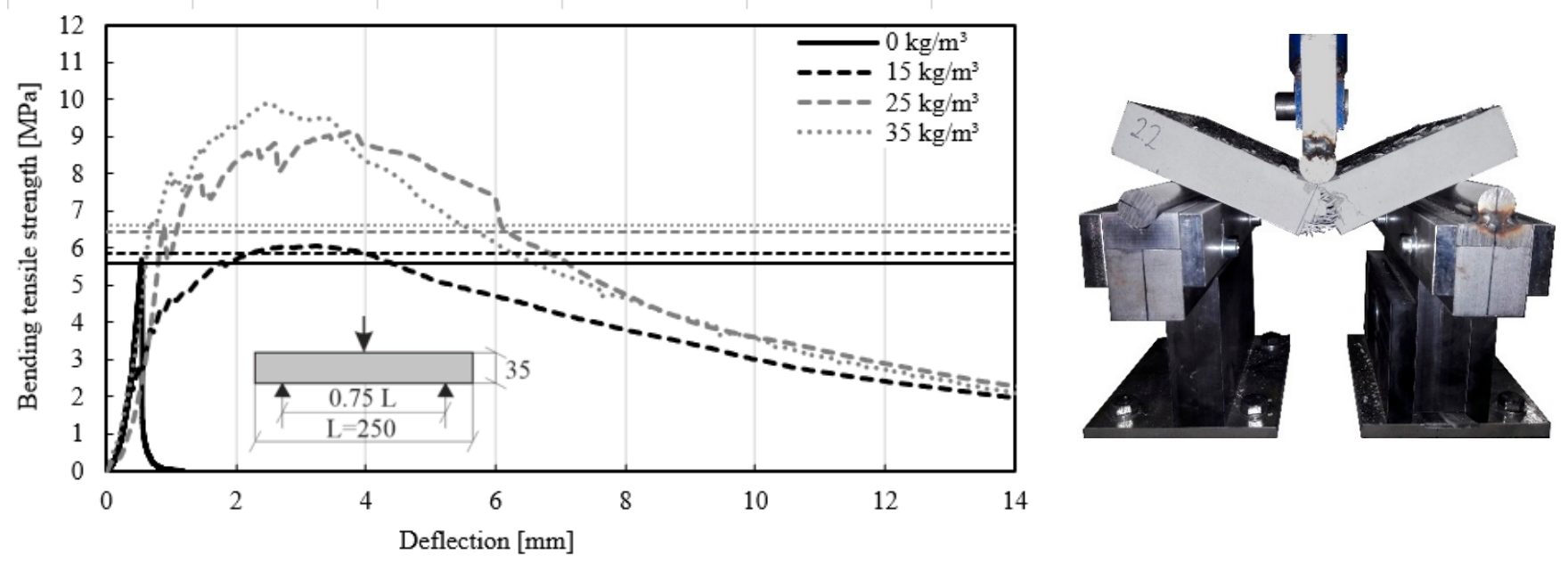

Figure 9. Bending-tensile strengths of concrete with different fiber dosages MasterFiber 235 SPA (PP) in accordance with EN 12467 [38].

Table 5. Bending tensile strength of concrete with different fiber dosages of MasterFiber 235 SPA (PP) in accordance with EN 12467 [38].

\begin{tabular}{ccccc}
\hline Mix ID & Type of Fiber & $\begin{array}{c}\text { Fiber-Dosage } \\
{\left[\mathbf{k g} / \mathbf{m}^{\mathbf{3}}\right]}\end{array}$ & $\begin{array}{c}f_{L} \text { [st. dev] } \\
{[\mathbf{M P a}]}\end{array}$ & $\begin{array}{c}\text { Percentage } \\
\text { Increase [\%] }\end{array}$ \\
\hline 2 & & 35 & $6.62[0.20]$ & 118 \\
3 & MasterFiber 235 & 25 & $6.43[0.16]$ & 115 \\
4 & SPA (PP) & 15 & $5.85[0.38]$ & 104 \\
5 & & 0 & $5.61[0.40]$ & 100 \\
\hline
\end{tabular}

The test results in Table 5 clearly reflect the addition of fiber dosage: an increasing bending tensile strength was observed with higher fiber dosage. The tests revealed an increase of up to $4 \%$ for a fiber dosage of $15 \mathrm{~kg} / \mathrm{m}^{3}, 15 \%$ for $2 \mathrm{~d} 5 \mathrm{~kg} / \mathrm{m}^{3}$, and $18 \%$ for $35 \mathrm{~kg} / \mathrm{m}^{3}$. The experiments showed that by adding fibers, the failure mode changed from brittle to ductile. Similar to the study conducted by Kahanji [56], the variation of the fiber dosage has an enormous influence on the post-crack behavior of HPFRC.

The same results as for the panels were achieved with beams according to EN 14651 [39]. Figure 10 presents the test results with CMOD and Figure 11 shows the results with a deflection in the middle span of the specimen. The stress-strain diagram shows that the strain increased immediately after crack initiation. A comparison of the test results obtained for mixtures ID $2\left(35 \mathrm{~kg} / \mathrm{m}^{3}\right)$ and ID $3\left(25 \mathrm{~kg} / \mathrm{m}^{3}\right)$ showed similar bending tensile strengths. However, the dosage of fiber quantity for mixtures ID 2 and 3 differed. By comparing these two fiber dosages, an increase in the bending tensile strength of up to $200 \%$ was evident. Mixture ID 4 showed increases of up to $84 \%$. The strain of mixture ID 4 measured with the clip gauge reached a plateau. Following this crack initiation, the measured strains increased with higher load capacity. For concrete without fibers (mixture ID 5), the stress-strain curve reached $3.14 \mathrm{MPa}$, then declined and reached zero. 


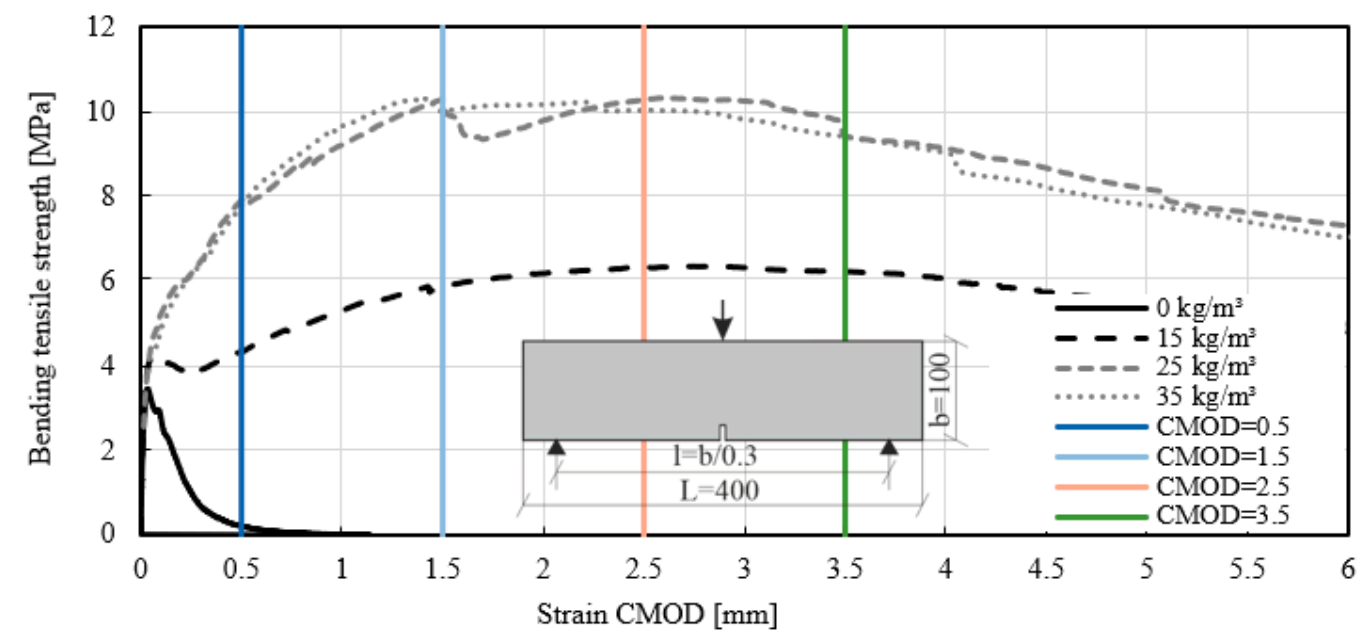

Figure 10. Stress-strain curves of the beam test-series with different fiber dosages MasterFiber 235 SPA (PP). Clip gauge strain in accordance with EN 14651 [39]. The vertical axes are CMOD 0.5 to CMOD 3.5.

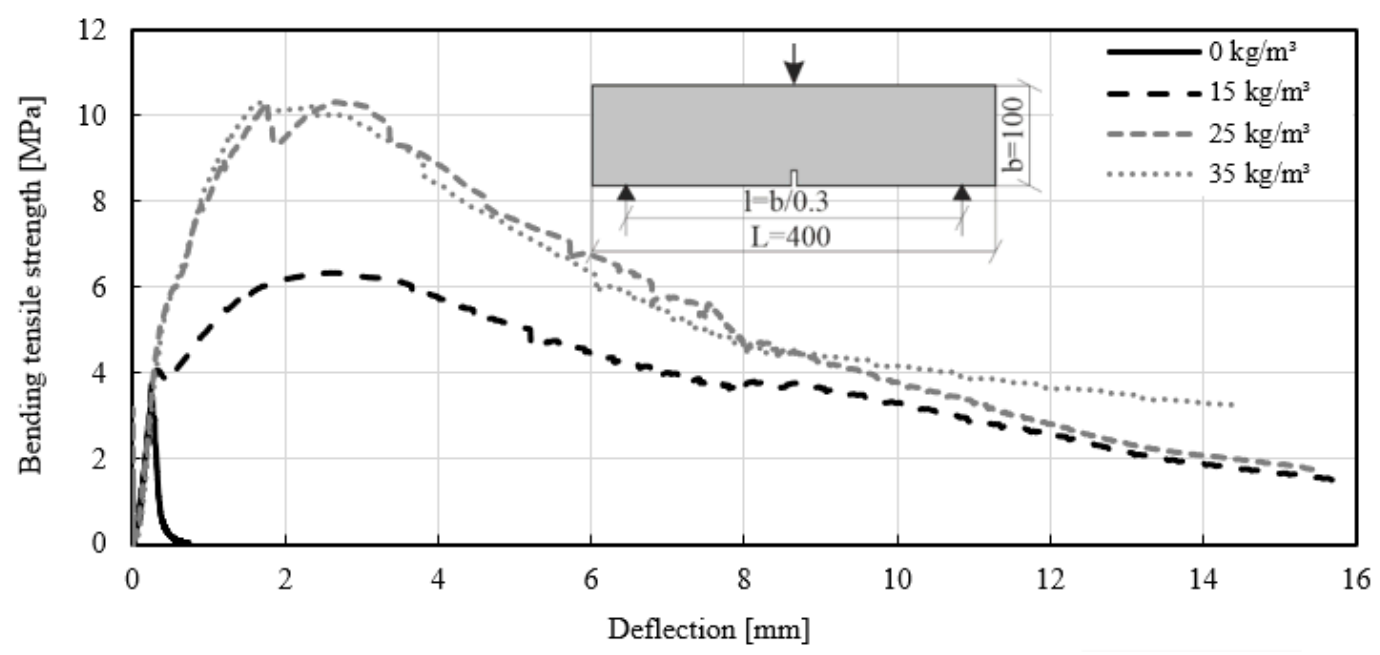

Figure 11. Stress-deflection curves of the beam test-series with different fiber dosages MasterFiber 235 SPA (PP).

The test method for fiber reinforced concrete presented in EN 14651 [39] enables the calculation of flexural tensile strength. The stresses $f_{L}$ in limit of proportionality (LOP) were calculated according to the equation for the test method in concrete with metallic fiber [39,57]. The required force was determined in the case of crack opening $\mathrm{CMOD}=0.05 \mathrm{~mm}$ (see Figure 12). The flexural tensile strength (limit of proportionality) was calculated and listed in Table 6 (characteristic values with $\mathrm{k}_{\mathrm{s}}=2.336$ ). The correlation of the stress-strain curves showed that with a fiber addition between $15 \mathrm{~kg} / \mathrm{m}^{3}$ and $35 \mathrm{~kg} / \mathrm{m}^{3}$, the results of LOP were similar. A significant difference was found in the post crack behavior due to the addition of fibers to the mix. The samples with Mix ID 5 failed when the maximum flexural stresses were reached. This means that the CMOD with a value higher than $0.5 \mathrm{~mm}$ could not be determined. 


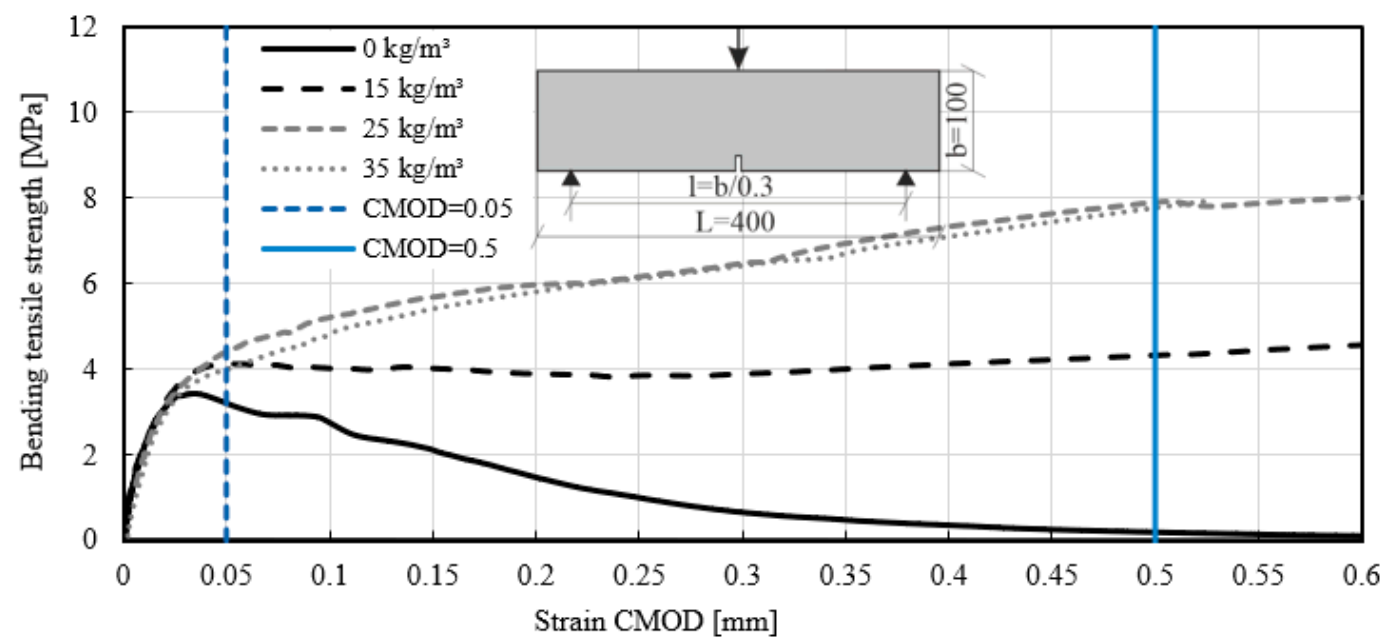

Figure 12. Stress-strain curves of the beam test-series with different fiber dosages MasterFiber 235 SPA (PP). Clip gauge strain in accordance with EN 14651 [39].

Table 6. Flexural tensile force according EN 14651 [39].

\begin{tabular}{|c|c|c|c|c|c|c|c|c|}
\hline \multirow{2}{*}{ Mix ID } & \multirow{2}{*}{$\begin{array}{c}\begin{array}{c}\text { Fiber- } \\
\text { Dosage }\end{array} \\
{\left[\mathrm{kg} / \mathrm{m}^{3}\right]}\end{array}$} & \multirow{2}{*}{$\begin{array}{c}\text { Type of } \\
\text { Fiber }\end{array}$} & \multirow{2}{*}{$\begin{array}{c}f_{L} \text { LOP } \\
{[\mathrm{MPa}]}\end{array}$} & \multirow{2}{*}{$\begin{array}{c}\text { Percentage } \\
\text { Increase } \\
{[\%]}\end{array}$} & \multicolumn{4}{|c|}{$f_{L}$ at Prescribed CMODj Values in MPa, [st. dev] } \\
\hline & & & & & $0.5[\mathrm{~mm}]$ & $1.5[\mathrm{~mm}]$ & $2.5[\mathrm{~mm}]$ & $3.5[\mathrm{~mm}]$ \\
\hline 2 & 35 & \multirow{4}{*}{$\begin{array}{c}\text { MasterFiber } \\
235 \text { SPA } \\
(\mathrm{PP})\end{array}$} & 3.89 [0.07] & 124 & $5.66[0.14]$ & $8.57[0.07]$ & $8.03[0.10]$ & $7.34[0.11]$ \\
\hline 3 & 25 & & $4.10[0.06]$ & 131 & $6.30[0.08]$ & $8.04[0.09]$ & $9.16[0.04]$ & $9.24[0.01]$ \\
\hline 4 & 15 & & $4.04[0.03]$ & 129 & $3.06[0.15]$ & $4.17[0.14]$ & $4.78[0.14]$ & $4.94[0.10]$ \\
\hline 5 & 0 & & 3.14 [0.09] & 100 & $0.11[0.22]$ & - & - & - \\
\hline
\end{tabular}

Based on experimental stress-strain curves, parameter $f_{L}$ was evaluated at four different CMOD values: $0.5,1.5,2.5$, and $3.5 \mathrm{~mm}$. The residual bending tensile strength $f_{L}$ for different fiber dosages was calculated and listed in Table 6 (characteristic values). This study allows for the following conclusions to be drawn in post-crack bending tensile strengths. With a fiber addition of $25 \mathrm{~kg} / \mathrm{m}^{3}$ and $35 \mathrm{~kg} / \mathrm{m}^{3}$, the maximum bending tensile strength varied between $6.30 \mathrm{MPa}$ and 5.66 MPa for CMOD of $0.5 \mathrm{~mm}$ and 9.24 MPa-7.34 MPa for CMOD of $3.5 \mathrm{~mm}$. For the fiber addition of $15 \mathrm{~kg} / \mathrm{m}^{3}$, the residual post-cracking strength reached 3.06 $\mathrm{MPa}$ for CMOD of $0.5 \mathrm{~mm}$ and $4.94 \mathrm{MPa}$ for CMOD of $3.5 \mathrm{~mm}$.

Figure 13 shows the stress-deflection curves of different fiber types. The first curve reflects the long MasterFiber 235 SPA (PP), and the second the short MasterFiber 401 (PVA). The short fiber is also thinner than the long fiber, which affects the mix design with a much higher number of fibers in the concrete. Both concrete mixtures were made of the same raw materials and comprised a fiber dosage of $35 \mathrm{~kg} / \mathrm{m}^{3}$. Although the PP fiber was longer than the PVA fiber, a similar maximum bending tensile strength was achieved with both types of material, regardless of the fiber length. In the study by Yoo [58], the authors reported that the use of a longer fiber led to higher flexural strength than the shorter fibers. In the experimental test, only strains as a function of the length of the fiber were detected. The stress-deflection curves for MasterFiber 235 SPA (PP) showed significantly better results than the stress-deflection curves for MasterFiber 401 (PVA) following a deflection of $6 \mathrm{~mm}$. The stress-deflection curve of fiber type MasterFiber 401 (PVA) revealed a higher increase in deflection compared to fiber type MasterFiber 235 SPA (PP), which may indicate unfavorable adhesion forces between PVA fiber and the matrix. Shorter fibers pull-out of the matrix faster than longer fibers. This is attributed to the bonding forces between the fibers and the concrete matrix. The $30 \mathrm{~mm}$ long fibers provided a better friction range than the $12 \mathrm{~mm}$ long fibers and also provided a better stress transfer in the matrix. However, 
the smaller fiber had a higher tensile strength. Different types of fibers reflect the bonding behavior between the fibers and the surrounding concrete [59].

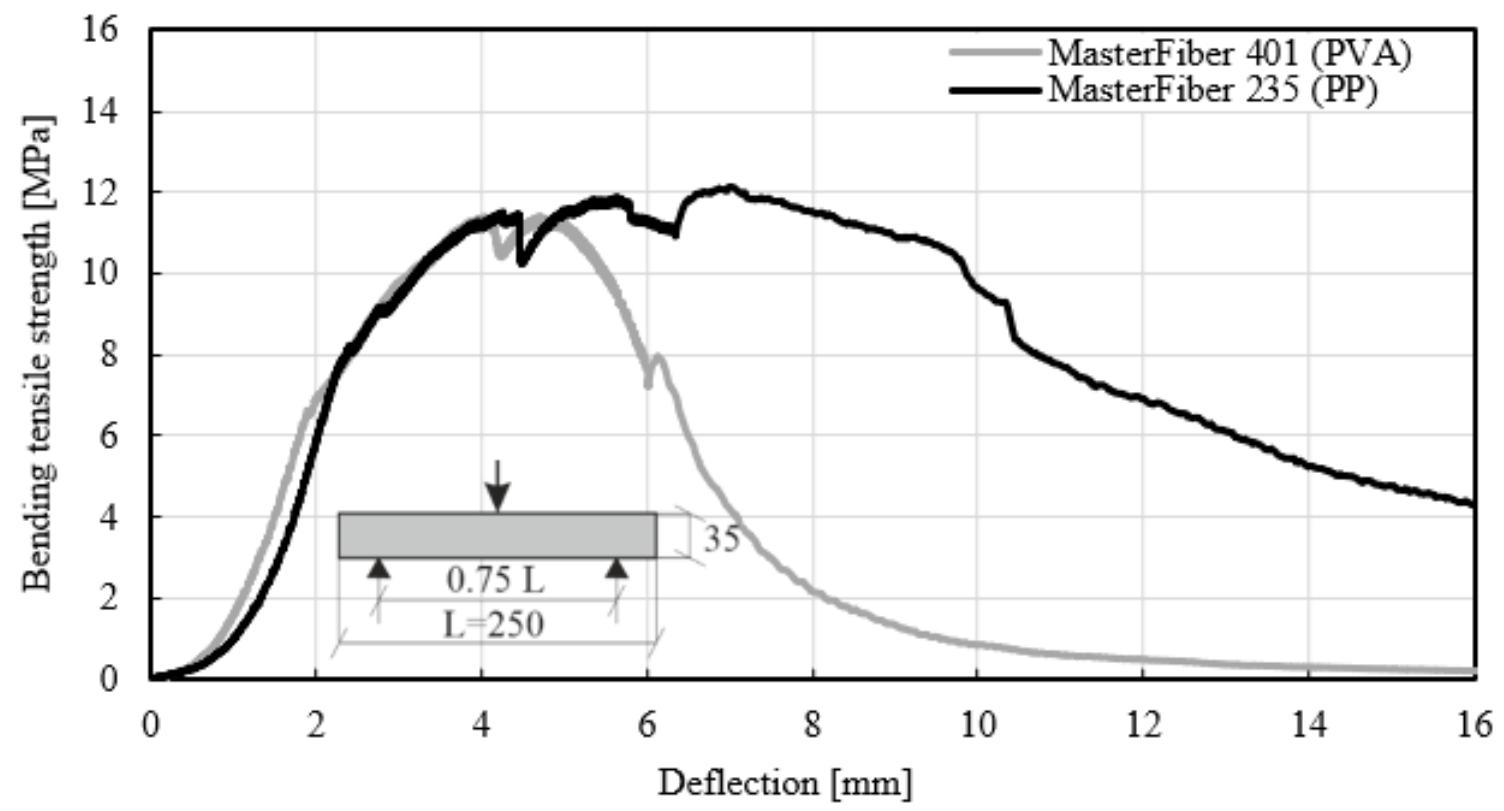

Figure 13. Bending-tensile strength of concrete with different fiber types (MasterFiber 235 SPA and MasterFiber 401) for a fiber dosage of $35 \mathrm{~kg} / \mathrm{m}^{3}$ in accordance with EN 12467 [38].

Figures 14-16 clearly show the cracking patterns of selected specimens in a three-point bending test. The main crack occurred in the middle of the specimen. During the loading tests, the crack width increased and lead to breakage or pull-out of the fiber. Due to the high strain rate of the materials, two halves of a concrete slab held together. There was no brittle failure because PP or PVA fibers under bending tensile load prevented the opening of a crack and finally prevented the sudden destruction of the concrete. The fibers, which were distributed along the axis of the beam, improved the bending tensile strength of the concrete. Some of the fibers in the crack zone reached their tensile strength.
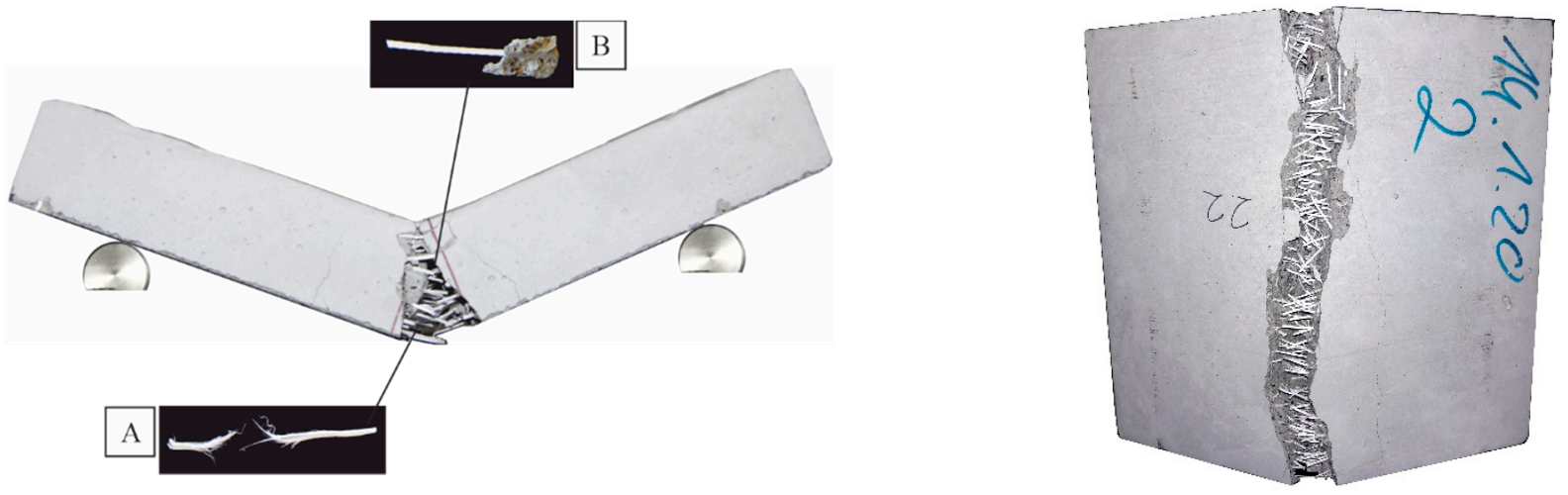

Figure 14. Typical failure modes for specimens [38] with MasterFiber 235 SPA (PP). (A) Images of the tensile fracture face of a fiber. (B) Images of the pull-out fracture face of a fiber. 

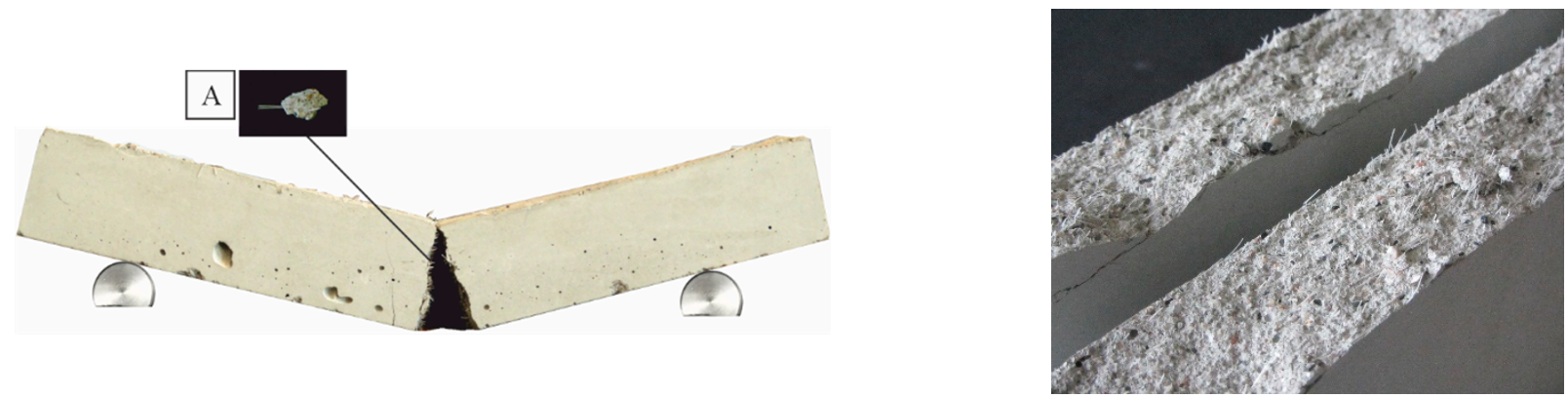

Figure 15. Typical failure modes for specimens [38] with MasterFiber 401 (PVA). (A) Images of the pull-out fracture face of a fiber.
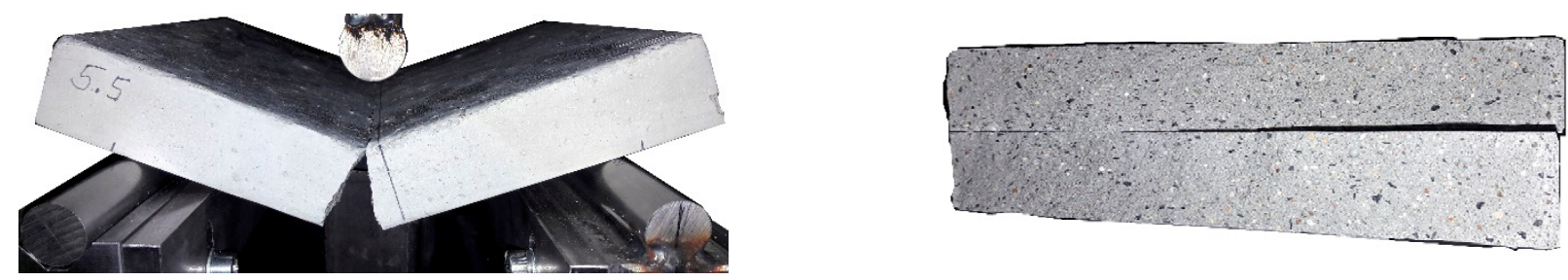

Figure 16. Typical failure modes for specimens [38] without fiber.

\section{Discussion}

As tests of the fresh and hardened concrete show, HPFRC is strongly affected by the density of used fiber and the presence of the air voids. The bulk density, compressive strength, and modulus of elasticity decreased with fiber addition. This effect can be attributable to fiber dosage in the concrete mix. Liu et al. [60] analyzed the permeability of carbon fiber reinforced concrete and observed the same impact based on the water-cement ratio. The fiber improves the impermeability of concrete only for the $\mathrm{w} / \mathrm{c}$ ratio of 0.25 . The higher ratio reduces the impermeability of hardened concrete. Richardson [61] studied the differences between plain concrete and concrete with fiber additions. Due to the higher air content in the fiber-reinforced mixtures compared to normal concrete, the compressive strengths differed from each other.

Another tendency showed in some cases of the normal strength concretes where the higher dosage increased compressive strength and modulus of elasticity. Kilmartin-Lynch et al. [62] tested a concrete mix with a compressive strength of $50.34 \mathrm{MPa}$ and reached higher values for the dosage of recycled polypropylene fibers. The increase of higher fiber dosage can be noted because the fibers became more densely spaced, which therefore increased compressive strength. Sekhar Das et al. [63] showed that the compressive strength of $36.9 \mathrm{MPa}$ initially increased with fiber content up to $0.5 \%$ and then decreased with further use of fibers. This content corresponds to a fiber dosage of $4.55 \mathrm{~kg} / \mathrm{m}^{3}$, which was not tested in the presented study. Therefore, the conclusion is that the correlation between compressive strength and modulus of elasticity depends on fiber dosage. For further studies, a lower fiber content should be tested.

In the experiment, the fiber dosage improved the flexural properties of concrete. The flexural strength increased the maximal $31 \%$ for a fiber dosage of $25 \mathrm{~kg} / \mathrm{m}^{3}$ in comparison to the plain concrete. Rostami et al. [64] reported that the highest flexural strength was $94 \%$ relative to the control sample. Such a large difference may be due to the length of the polypropylene fiber. In their experiment, Rostami et al. used longer PP fibers of $48 \mathrm{~mm}$. Similar observations were made by Zhou et al. [65] who reported that PP improved the flexural strength of concrete. Unfortunately, the tests were carried out on another type of fiber with a maximal length of $18 \mathrm{~mm}$.

Not only are the values of the flexural strength reflected in the studies on FRC, but the failure modes for specimens in flexural tests show similarities with other research. Abbas 
et al. [66] tested tunnel lining segments using UHPC with fiber dosage where the crack developed during the progression of load in the middle part of the sample.

\section{Conclusions}

The objective of this work was to investigate how fiber dosage affects the mechanical parameters of high-performance fiber reinforced concrete. This study allows for the following conclusions to be drawn in the area of material properties:

- The percentage of air voids in the concrete corresponds to the compressive strength and the modulus of elasticity of the concrete. A significant difference was found in the compressive strength of the concrete due to the addition of fibers to the mix. The fiber addition of $15 \mathrm{~kg} / \mathrm{m}^{3}$ in the concrete composition reduced the compressive strength from 83.2 MPa to 79.6 MPa. The higher fiber dosage showed a similar trend. Furthermore, it reduced compressive strength and the modulus of elasticity of the concrete.

- PP and PVA fibers have proven to be effective in increasing the splitting tensile strength of concrete, which allows better utilization of material capacities and has an impact on the production costs of FRC members. The comparison showed that the dosage of fibers increased from 4.0 MPa to $5.0 \mathrm{MPa}\left(\right.$ for $\left.15 \mathrm{~kg} / \mathrm{m}^{3}\right), 6.7 \mathrm{MPa}\left(25 \mathrm{~kg} / \mathrm{m}^{3}\right)$, and $6.9 \mathrm{MPa}\left(35 \mathrm{~kg} / \mathrm{m}^{3}\right)$.

- The analysis of the bending tensile tests revealed differences between MasterFiber 401 (PVA) and MasterFiber 235 SPA (PP) in the post-crack phase. MasterFiber 235 SPA is intended to be used because of its higher ductility.

- The bridging effect, which improves the safety of the concrete components, was identified in the bending tensile test. The bending tensile strength of concrete with added fibers increased by up to $18 \%$ compared to materials without fibers. Some of the fibers reached their tensile strength and were no longer involved in the transfer of the load. The pull-out effect of the fiber changed the brittle fracture behavior of concrete into the ductility behavior of these materials.

- In the present study, the highest PP fiber dosage examined in the concrete composition amounted to $35 \mathrm{~kg} / \mathrm{m}^{3}$. However, the addition of more than $25 \mathrm{~kg} / \mathrm{m}^{3}$ of fibers to the concrete mix had less influence on the bending tensile strength of the concrete. This concrete mix had an overcritical fiber dosage and was characterized by tensile strain-hardening behavior. A comparison of the stress-deflection curves with the addition of $25 \mathrm{~kg} / \mathrm{m}^{3}$ and $35 \mathrm{~kg} / \mathrm{m}^{3}$ of fibers revealed that the cracking behavior of concrete for these two fiber contents did not differ significantly.

- Further study of HPFRC comprises more mechanical experiments. New attempts will be focused on anchorage techniques for façade plates in building construction. A higher load capacity for the steel anchor system with a higher fiber dosage is expected.

Author Contributions: Conceptualization, S.G., M.P., M.S.-C. and S.H.; methodology, S.G., M.P., M.S.-C. and S.H.; investigation, S.G. and S.H.; writing-original draft preparation, S.G. and S.H.; writing—review and editing, S.G., M.P., M.S.-C., S.H. and C.H.; supervision, S.G., M.P., M.S.-C., S.H. and C.H.; project administration, M.P., M.S.-C. and C.H.; funding acquisition, M.P., M.S.-C. and C.H. All authors have read and agreed to the published version of the manuscript.

Funding: This research was funded by the Master Builders Solutions Deutschland GmbH.

Institutional Review Board Statement: Not applicable.

Informed Consent Statement: Not applicable.

Data Availability Statement: Not applicable.

Acknowledgments: This research work was supported by Master Builders Solutions Deutschland $\mathrm{GmbH}$. The authors would like to thank the staff of the Civil Engineering Department of Technical University in Kaiserslautern for the support extended during the experimental works carried out in the laboratory. 
Conflicts of Interest: The authors declare no conflict of interest.

\section{References}

1. Hegger, J.; Zell, M.; Horstmann, M. Textile Reinforced Concrete-Realization in applications. In Tailor Made Concrete StructuresWalraven E Stoelhorst, Proceedings of the International FIB symposium Amsterdam, The Netherlands, 19-22 May 2008; Taylor \& Francis Group: London, UK, 2008; pp. 357-362.

2. Schultz-Cornelius, M.; Pahn, M. Development of an innovative experiment set-up for filigree (U)HPC-facades. In Proceedings of the IV German-Polish PhD Symposium Kaiserslautern, Annweiler am Trifels, Germany, 2-5 July 2014; pp. 145-151.

3. Bund, B.; Breit, W. Prediction and verification of the distribution of fibers in fine grain systems. In Proceedings of the IV German-Polish PhD Symposium Kaiserslautern, Annweiler am Trifels, Germany, 2-5 July 2014; pp. 1-8.

4. Pinkerton, L.; Stecher, J.; Novak, J. Twisted Steel Micro Reinforcement. Concr. Int. 2013, 35, 1-14.

5. Juhasz, P.K.; Schaul, P. Design of Industrial Floors-TR34 and Finite Element Analysis (Part 2). J. Civ. Eng. Archit. 2019, 13, 512-522. [CrossRef]

6. Boita, I.-E.; Dan, D.; Stoian, V. Seismic Behaviour of Composite Steel Fibre Reinforced Concrete Shear Walls. IOP Conf. Series: Mater. Sci. Eng. 2017, 245, 22006. [CrossRef]

7. Lachance, F.; Charron, J.-P.; Massicotte, B. Development of Precast Bridge Slabs in High-Performance Fiber-Reinforced Concrete and Ultra-High-Performance Fiber-Reinforced Concrete. ACI Struct. J. 2016, 113. [CrossRef]

8. Mateckova, P.; Bilek, V.; Sucharda, O. Comparative Study of High-Performance Concrete Characteristics and Loading Test of Pretensioned Experimental Beams. Crystals 2021, 11, 427. [CrossRef]

9. Ali, B.; Raza, S.S.; Hussain, I.; Iqbal, M. Influence of different fibers on mechanical and durability performance of concrete with silica fume. Struct. Concr. 2021, 22, 318-333. [CrossRef]

10. Yoo, D.-Y.; Yoon, Y.-S. A Review on Structural Behavior, Design, and Application of Ultra-High-Performance Fiber-Reinforced Concrete. Int. J. Concr. Struct. Mater. 2016, 10, 125-142. [CrossRef]

11. Heinzle, G.; Freytag, B.; Linder, J. Rissbildung von biegebeanspruchten Bauteilen aus Ultrahochfestem Faserbeton. Beton Und Stahlbetonbau 2009, 104, 570-580. [CrossRef]

12. Marcos-Meson, V.; Michel, A.; Solgaard, A.; Fischer, G.; Edvardsen, C.; Lund, S. Corrosion resistance of steel fiber reinforced concrete-a literature review. In Performance-Based Approaches for Concrete Structures: Proceedings; Fib Symposium: Cape Town, South Africa, 2016.

13. Herr, C.M.; Lombardi, D.; Galobardes, I. Parametric Design of Sculptural Fibre Reinforced Concrete Facade Components. In Proceedings of the 23rd International Conference of the Association for Computer-Aided Architectural Design Research in Asia (CAADRIA), Beijing, China, 17-19 May 2018; 2018; 2, pp. 319-328.

14. Abdel-Mooty, M.; Shaaban, S. Nonlinear dynamic response of RC building fasade panels to impact loads. Struct. Under Shock. Impact XII 2012, 126, 281-291. [CrossRef]

15. Baby, F.; Graybeal, B.; Marchand, P.; Toutlemonde, F. Identification of UHPFRC tensile behaviour: Methodology based on bending tests. In Proceedings of the Symposium on Ultra-High Performance Fiber-Reinforced Concrete, UHPFRC, Marseille, France, 1-3 October 2013.

16. Banyhussan, Q.; Yildirim, G.; Anil, Ö.; Erdem, R.; Ashour, A.; Sahmaran, M. Impact resistance of deflection-hardening fiberreinforced concretes with different mixture parameters. Struct. Concr. 2019, 1-29. [CrossRef]

17. Foglar, M.; Hajek, R.; Fladr, J.; Pachman, J.; Stoller, J. Full-scale experimental testing of the blast resistance of HPFRC and UHPFRC bridge decks. Constr. Build. Mater. 2017, 145, 588-601. [CrossRef]

18. Ehrenbring, H.Z.; Quinino, U.C.D.M.; Oliveira, L.F.S.; Tutikian, B.F. Experimental method for investigating the impact of the addition of polymer fibers on drying shrinkage and cracking of concretes. Struct. Concr. 2019, 20, 1064-1075. [CrossRef]

19. Onuaguluchi, O.; Banthia, N. Plant-based natural fiber reinforced cement composites: A review. Cem. Concr. Compos. 2016. [CrossRef]

20. Jalasutram, S.; Sahoo, D.R.; Matsagar, V. Experimental investigation of the mechanical properties of basalt fiber-reinforced concrete. Struct. Concr. 2017. [CrossRef]

21. Shakor, P.; Pimplikar, S. Glass Fiber Reinforced Concrete Use in Construction. Int. J. Technol. Eng. Syst. $2011,2$.

22. Granju, J.; Balouch, S. Corrosion of steel fiber reinforced concrete from the cracks. Cem. Concr. Res. 2005, 35, 572-577. [CrossRef]

23. Hassan, A.; Jones, S.; Mahmud, G. Experimental test methods to determine the uniaxial tensile and compressivebehaviour of ultra high performance fiber reinforced concrete (UHPFRC). Constr. Build. Mater. 2012, 37, 874-882. [CrossRef]

24. Schultz-Cornelius, M.; Pahn, M. Influence of the Size Effect on the Flexural Tensile Strength of Filigree UHPC Components. In Proceedings of the Young Researchers Symposium, Kaiserslautern, German, 14-15 April 2016.

25. Duque, L.F.M.; Graybeal, B. Fiber orientation distribution and tensile mechanical response in UHPFRC. Mater. Struct. 2016, 50. [CrossRef]

26. Graybeal, B.; Baby, F.; Marchand, P.; Toutlemonde, F. Direct and Flexural Tension Test Methods for Determination of the Tensile Stress-Strain Response of UHPC. In Ultra-High Performance Concrete and Nanotechnology in Construction, Proceedings of the Hipermat 2012 3rd International Symposium on UHPC and Nanotechnology for High Performance Construction Materials, Kassel, Germany, 7-9 March 2012; Kassel University Press GmbH: Kassel, Germany, 2008; pp. 395-402. 
27. Prudencio, L.; Austin, S.; Jones, P.; Armelin, H.; Robins, P. Prediction of steel fiber reinforced concrete under flexure from an inferred fiber pull-out response. Mater. Struct. 2006, 39, 601-610. [CrossRef]

28. Sakr, M.A.; Sleemah, A.A.; Khalifa, T.M.; Mansour, W.N. Shear strengthening of reinforced concrete beams using prefabricated ultra-high performance fiber reinforced concrete plates: Experimental and numerical investigation. Struct. Concr. 2019, 20, 1137-1153. [CrossRef]

29. EN 197-1: Cement-Part 1: Composition, Specifications and Conformity Criteria for Common Cements; Beuth Verlag GmbH: Berlin, Germany, 2011.

30. EN 13139. Aggregates for Mortar; Beuth Verlag GmbH: Berlin, Germany, 2002.

31. EN 12620. Aggregates for Concrete; Beuth Verlag GmbH: Berlin, Germany, 2008.

32. EN 933-1. Tests for Geometrical Properties of Aggregates-Part 1: Determination of Particle Size Distribution-Sieving Method. 2012. Available online: https://standards.iteh.ai/catalog/standards/cen/100b983f-85a4-4a80-934c-e93c584dbdb4/en-933-12012 (accessed on 7 June 2021).

33. Sofi, A.; Sinha, R.; Bhattacharya, S. Mechanical Properties of Concrete Containing Polypropylene Fiber and Silica Fume. Int. J. Civ. Eng. Technol. 2017.

34. Ludwig, H.-M.; Linß, E. Report: Grading of the Fines for Microsilica; FIB-F. A. Finger-Institut für Baustoffkunde: Weimar, Germany, 2012.

35. SH Minerals GmbH. Report: Grading of the Fines for Limestone Powder: Product: Sh_compact I; SH Minerals GmbH: Heidenheim, Germany, 2020.

36. EN 12390-1: Testing Hardened Concrete-Part 1: Shape, Dimensions and Other Requirements for Specimens and Moulds; Beuth Verlag GmbH: Berlin, Germany, 2019.

37. EN 12390-3: Testing Hardened Concrete_Part 3: Compressive Strength of Test Specimens; Beuth Verlag GmbH: Berlin, Germany, 2019.

38. EN 12467:2012+A1:2016, Fiber-Cement Flat Sheets-Product Specification and Test Methods; Beuth Verlag GmbH: Berlin, Germany, 2016.

39. EN 14651:2005+A1:2007, Test Method for Metallic Fiber Concrete-Measuring the Flexural Tensile Strength (Limit or Proportionality (LOP), Residual); Beuth Verlag GmbH: Berlin, Germany, 2007.

40. Pajak, M.; Ponikiewski, T. Flexural behavior of self-compacting concrete reinforced with differenttypes of steel fibers. Constr. Build. Mater. 2013, 47, 397-408. [CrossRef]

41. Harenberg, S.; Pahn, M.; Malárics-Pfaff, V.; Dehn, F.; Caggiano, A.; Schicchi, D.; Yang, S.; Koenders, E. Digital image correlation strain measurement of ultra-highperformance concrete-prisms under static and cyclic bendingtensile stress. Struct. Concr. 2019, 20, 1220-1230. [CrossRef]

42. Bi, J.; Zhao, Y.; Guan, J.; Huo, L.; Qiao, H.; Yuan, L. Three-dimentional modeling of the distribution and orientation of steel fibers during the flow of self-compacting concrete. Struct. Concr. 2019, 20, 1722-1733. [CrossRef]

43. Fib Model Code for Concrete Structures; Ernst \& Sohn: Berlin, Germany, 2010.

44. EN 12350-5: Testing Fresh Concrete-Part 5: Flow Table Test; Beuth Verlag GmbH: Berlin, Germany, 2009.

45. Aslani, F.; Sun, J.; Bromley, D.; Ma, G. Fiber-reinforced lightweight self-compacting concrete incorporating scoria aggregates at elvated temperatures. Struct. Concr. 2019, 20, 1022-1035. [CrossRef]

46. Chen, Y.; Matalkah, F.; Weerasiri, R.; Balachandra, A.; Soroushian, P. Despersion of Fibers in Ultra-High-Performance Concrete. Concr. Int. 2017, 39, 45-50.

47. EN 12350-7: Testing Fresh Concrete-Part 7: Air Dosage Pressure Methods; Beuth Verlag GmbH: Berlin, Germany, 2009.

48. Hassan, M.; Abo Sabah, S.; Bunnori, N.; Megat Johari, M. Fluid transport properties of normal concrete overlay composite. Structural Concrete 2019.

49. Aslani, F.; Hou, L.; Nejadi, S.; Sun, J.; Abbasi, S. Experimental analysis of fiber-reinforcement recycled aggregate self-compacting concrete using waste recycled concrete aggregates. Struct. Concr. 2019, 20, 1771-1780. [CrossRef]

50. Meesala, C.R. Influence of different types of fibreon the properties of recycled aggregate concrete. Struct. Concr. 2019, 20, 1656-1669. [CrossRef]

51. EN 12390-13: Testing Hardened Concrete-Part 13: Determination of Secant Modulus of Elasticity in Compression; Beuth Verlag GmbH: Berlin, Germany, 2019.

52. Zhang, R.; Jin, L.; Tian, Y.; Dou, G.; Du, X. Static and dynamic mechanical properties of eco-friendly polyvinyl alcohol fiberreinforced ultra-high-strength concrete. Struct. Concr. 2019, 20, 1051-1063. [CrossRef]

53. Hegger, J.; Will, N.; Voss, S. Textile Reinforced Concrete Facades. Concrete Structures: The Challenge of Creativity fib Symposium. Struct. Concr. 2004.

54. Association Francaise de Genie Civil. Bétons Fibrés á Ultra-Hautes Performances; AFGC: Paris, France, 2013.

55. Karatas, M.; Dener, M.; Benli, A.; Mohabbi, M. High temperature effect on the mechanical behaviour of steel fiber reinforced self-compacting concrete containing ground pumice powder. Struct. Concr. 2019, 20, 1734-1749. [CrossRef]

56. Kahanji, C.; Ali, F.; Nadjai, A. Structural performance of ultra-high-performance fiber-reinforced concrete beams. Struct. Concr. 2017, 18, 249-258. [CrossRef]

57. DAfStb Guideline 2010, Deutscher Ausschuss für Stahlbeton e. V.-DafStb; Beuth Verlag GmbH: Berlin, Germany, 2010.

58. Yoo, D.-Y.; Banthia, N.; Yoon, Y.-S. Impact Resistance of Reinforced Ultra-High-Performance Concrete Beams with Different Steel Fibers. ACI Struct. J. 2017, 114. [CrossRef] 
59. Lee, D.H.; Han, S.-J.; Kim, K.S.; LaFave, J.M. Shear capacity of steel fiber-reinforced concrete beams. Struct. Concr. 2017, 18, 278-291. [CrossRef]

60. Liu, R.; Xiao, H.; Liu, M.; Li, Y.; Geng, J. Effect of carbon fiber on properties of concrete withdifferent W/C and its air-entraining models. Struct. Concr. 2021, 22. [CrossRef]

61. Richardson, A.E. Compressive strength of concrete with polypropylene fibre additions. Struct. Surv. 2006, 24, 138-153. [CrossRef]

62. Kilmartin-Lynch, S.; Saberian, M.; Li, J.; Roychand, R.; Zhang, G. Preliminary evaluation of the feasibility of using polypropylene fibres from COVID-19 single-use face masks to improve the mechanical properties of concrete. J. Clean. Prod. 2021, 296, 126460. [CrossRef] [PubMed]

63. Das, C.S.; Dey, T.; Dandapat, R.; Mukharjee, B.B.; Kumar, J. Performance evaluation of polypropylene fibre reinforced recycled aggregate concrete. Constr. Build. Mater. 2018, 189, 649-659. [CrossRef]

64. Rostami, R.; Zarrebini, M.; Abdellahi, S.B.; Mostofinejad, D.; Abtahi, S.M. Investigation of flexural performance of concrete reinforced with indented and fibrillated macro polypropylene fibers based on numerical and experimental comparison. Struct. Concr. 2021, 22, 250-263. [CrossRef]

65. Zhou, X.; Zeng, Y.; Chen, P.; Jiao, Z.; Zheng, W. Mechanical properties of basalt and polypropylene fibre-reinforced alkali-activated slag concrete. Constr. Build. Mater. 2021, 269, 121284. [CrossRef]

66. Abbas, S.; Nehdi, M.L. Mechanical Behavior of Ultrahigh-Performance Concrete Tunnel Lining Segments. Materials 2021, 14, 2378. [CrossRef] 